\title{
N-Acetylcysteine Mitigates Histopathological and Ultrastructural Alterations Induced by Chronic Usage of Acetaminophen in the Rat Renal Cortex
}

\author{
Original \\ Article \\ Awny Hasan Yaseen, Samar Adel Asker, Nesreen Moustafa Omar, \\ Amany Abd El Fattah Abd El Fattah \\ Department of Medical Histology and Cell Biology, Faculty of Medicine, Mansoura University, \\ Egypt
}

\begin{abstract}
Background: Acetaminophen or N-acetyl-p-aminophenol (APAP) is a potent analgesic and antipyretic drug that is widely used. N-Acetylcysteine (NAC) is a synthetic antioxidant, acting as a free radical scavenger.

Aim of the work: This work was designed to demonstrate the effect of NAC on the histological changes induced by chronic usage of acetaminophen in the renal cortex.

Materials and methods: Forty male albino rats distributed into four groups were utilized. Control group: given distilled water. NAC-group: given NAC (150 mg/kg/day), orally, once daily for 4 weeks. Aceta-group: given Acetaminophen (APAP $300 \mathrm{mg} / \mathrm{kg}$ /day) orally, once daily for 4 weeks. Aceta+NAC group: given Acetaminophen (APAP $300 \mathrm{mg} / \mathrm{kg} / \mathrm{day}$ ) orally then NAC $(150 \mathrm{mg} / \mathrm{kg})$ orally 2 hours after oral APAP, once daily for 4 weeks. Small specimens of the renal cortex were obtained and processed for light and electron microscopic studies. Blood urea nitrogen (BUN) and serum creatinine levels were assessed. Morphometric and statistical studies were also performed.

Results: Chronic usage of acetaminophen resulted in distortion and shrinkage of some glomeruli and partial destruction of Bowman's capsule. Proximal convoluted tubules showed dilatations, degenerative changes and loss of the apical brush border. Mononuclear cellular infiltration and deposition of collagenous fibers in the renal interstitium were also demonstrated. By electron microscope, glomerular basement membrane showed irregular thickening and loss of its trilaminar appearance. Cells lining the proximal convoluted tubules showed dense irregular nucleus, cytolplasmic vacuoles and loss of apical microvilli. These changes were accompanied by significant elevations in the serum levels of BUN and creatinine. NAC administration provoked partial improvement in the renal histology and a significant decline in serum levels of BUN and creatinine.

Conclusion: N-acetylcysteine could attenuate histological and biochemical changes induced by chronic usage of acetaminophen in the rat renal cortex.
\end{abstract}

Received: 03 October 2018, Accepted: 08 November 2018

Key Words: Acetaminophen; N-acetylcysteine; nephrotoxicity; ultrastucture.

Corresponding Author: Nesreen Moustafa Omar, MD, Department of Medical Histology and Cell Biology, Faculty of Medicine, Mansoura University, Egypt, Tel.: +20 100645 0090, Fax: +20502397900, E-mail: nesrinemoustafa@gmail.com ISSN: $1110-0559$, Vol. 42, No. 1

\section{INTRODUCTION}

Acetaminophen or N-acetyl-p-aminophenol (APAP) is the most widely used analgesic in the world. At therapeutic doses, it is an effective and safe analgesic and antipyretic drug $^{[1]}$. Acetaminophen is useful in mild to moderate pain such as headache, toothache, fever, myalgia, and postpartum pain. It is a major component of numerous cold and flu remedies, and commonly utilized in treatment of more severe pain like post-surgical pain. It is also used in combination with opioids as a palliative treatment for pain due to cancer ${ }^{[2,3]}$.

Therapeutic doses of APAP may cause nausea, skin rash and minor allergic reaction. With larger doses, anorexia, nausea, vomiting, dizziness, excitement, and disorientation may occur. Renal tubular necrosis, hepatic necrosis and hypoglycemic coma may also occur in prolonged, largedose therapy ${ }^{[4,5]}$.

Kidneys are highly vulnerable to drug induced nephrotoxicity since they are primarily involved in concentrating and elimination of various chemicals and drugs. The availability of APAP and wide range of its therapeutic uses greatly increased the incidence of APAP-induced renal injury. Acute and chronic nephrotoxicities caused by APAP were previously reported $^{[2,6]}$. The mechanism of APAP nephrotoxicity is less clearly understood. Cytochrome P-450 (CYP450) enzymes, glutathione S-transferase, prostaglandins (PGs) endoperoxidase synthase, and N-deacetylase are hypothesized to be involved in APAP-induced renal toxicity ${ }^{[6,7]}$. 
$\mathrm{N}$-Acetylcysteine (NAC) is a famous synthetic, thiolcontaining antioxidant, acting as a free radical scavenger. It is also used as a mucolytic agent to liquefy thick mucus in a variety of respiratory conditions such as emphysema, bronchitis, cystic fibrosis, and pneumonia. In addition, it is beneficial as an antidote in the treatment of APAP hepatotoxicity ${ }^{[8,9]}$.

Prior studies have suggested that APAP toxicity could be prevented by early treatment with NAC ${ }^{[10,11]}$. Other workers reported that NAC protects against APAP hepatotoxicity but, it has a limited function towards APAP-induced renal damage ${ }^{[12,13]}$. Therefore, the purpose of this study was to ascertain whether NAC administration could attenuate the histological and ultrastructural insults induced by chronic usage of APAP in the rat renal cortex.

\section{MATERIALS AND METHODS}

\section{Experimental Animals}

All the experimental procedures were performed with pre-approval from the ethics committee of Mansoura Faculty of Medicine (Institutional Research Board, IRB). The duration of the experiment was 4 weeks. Forty adult male albino rats obtained from the animal house of Mansoura Faculty of Medicine were utilized in this study. The weights of animals were ranging from 150 to 250 grams. The rats were kept in metal cages in average temperature $(22-25 \mathrm{C} \circ)$, average humidity (50-55\%), regular $12 \mathrm{~h}$ light $/ 2 \mathrm{~h}$ dark cycle and given food and water ad-libitum.

\section{Animal grouping}

The animals were distributed randomly into four equal groups, 10 rats each.

1. Control group: given distilled water (D.W.) orally by gastric tube, once daily for 4 weeks.

2. NAC-group: given NAC $(150 \mathrm{mg} / \mathrm{kg} /$ day $)$ dissolved in D.W., orally by gastric tube, once daily for 4 weeks. N-Acetylcysteine was obtained from Sigma chemical company, St. Louis, MO, USA).

3. Aceta-group: rats were given Acetaminophen (APAP $300 \mathrm{mg} / \mathrm{kg} /$ day) dissolved in D.W., orally by gastric tube, once daily for 4 weeks. Acetaminophen "Novadol®" was purchased from Sanovi Aventis Phamaceutical Company, Cairo, Egypt.

4. Aceta+NAC group: rats were given Acetaminophen (APAP $300 \mathrm{mg} / \mathrm{kg} /$ day) orally then NAC (150 mg/ $\mathrm{kg}$ ) orally 2 hours after oral APAP, once daily for 4 weeks.

NAC and APAP doses, route of administration and durations were used following previous studies ${ }^{[11,14]}$.

At the end of the experiment, the rats were anaesthetized by $50 \mathrm{mg} / \mathrm{kg}$ intraperitoneal injection of thiopental ${ }^{[15]}$.
Blood samples were obtained from the tail vein to determine blood urea nitrogen (BUN) and creatinine levels. After anesthesia, the animals were perfused in the left ventricle with $150 \mathrm{ml}$ isotonic saline followed by freshly prepared $150 \mathrm{ml}$ of $4 \%$ buffered paraformaldehyde (pH 7.3). Laparotomy was done and the two kidneys of each rat were dissected.

\section{Histological study}

\section{Light microscopy}

Small specimens $(0.5 \times 0.5 \times 0.5 \mathrm{~cm})$ from the renal cortex were fixed in $10 \%$ neutral buffer formalin, dehydrated, cleared and embedded in paraffin wax. Paraffin sections $(5 \mu \mathrm{m})$ were prepared and stained with Hematoxylin $\& \operatorname{Eosin}^{[16]}$, PAS $^{[17]}$ and Mallory's trichrome ${ }^{[18]}$ stains.

\section{Ultrastuctural study}

Small pieces $(1 \mathrm{~mm} 3)$ from the renal cortex were processed for transmission electron microscopic study. The specimens were first fixed in $0.1 \mathrm{~mol} / \mathrm{L}$ phosphate buffer containing $2.5 \%$ glutaraldehyde and $2 \%$ paraformaldehyde at $4{ }^{\circ} \mathrm{C}$ for $2-4$ hours in the refrigerator, then post-fixed in $1 \%$ osmium tetraoxide for two hours at $4{ }^{\circ} \mathrm{C}$. Dehydration was accomplished in graded ethanol. The specimens were then immersed in a mixture of equal volumes of ethanol $(100 \%)$ and acetone $(100 \%)$ for 15 minutes, then, in acetone $(100 \%)$ for another 15 minutes. Then, the specimens were put in equal volumes of epon and acetone for one hour, then 25:50 acetone: epon for one hour, finally immersed in epon only in embedding capsules and placed in a 60 $\mathrm{C}^{\mathrm{o}}$ oven overnight for polymerization. Semithin sections $(1 \mu \mathrm{m})$ were cut and stained with toluidine blue $1 \%$ solution for one minute. These sections were examined by the light microscope to select the sites for ultrathin sectioning. Ultrathin sections $(60 \mathrm{~nm})$ were cut by new freshlyprepared glass knives. The sections were then picked on copper grids. The sections were stained by double staining techniques of $2 \%$ uranyl acetate for 10 minutes followed by Reynold's lead citrate solution for 10 minutes. The specimens were examined by (TEM JEOL JEM- 100 SX) in electron microscopy unit, Faculty of Agriculture, Mansoura University ${ }^{[19]}$.

\section{Biochemical analysis}

The levels of blood urea nitrogen $(\mathrm{BUN})^{[20]}$ and creatinine ${ }^{[21]}$ were assessed as measures of renal injury.

\section{Morphometric study}

Using image $\mathrm{J}$ program the following measurements were obtained from the photomicrographs and electron micrographs of the renal cortex:

1. The mean diameter of the renal corpuscles (MCD) was measured in five photomicrographs of $\mathrm{H} \& \mathrm{E}$ stained sections X100 per animal for all groups.

2. The percent of shrunken renal corpuscles $(\mathrm{MCD} \leq 70 \mathrm{um})$ was calculated in five 
photomicrographs of H\&E stained sections X100 per animal for all groups.

3. The percent area of collagenous fibers was measured in five photomicrographs of Mallory's trichrome stained sections X100 per animal for all groups.

4. The percent area of PAS positive reaction was measured in five photomicrographs of PAS stained sections X100 per animal for all groups.

5. Thickness of the glomerular basement membrane was measured in five electron micrographs per animal for all groups.

\section{Statistical study}

Computer program Statistical Package for Social Science (SPSS) version 20.0 (IBM Corporation, NY, USA) was used. Data were represented as mean \pm SD. In the statistical comparison between the different groups, the significance of difference was tested using analysis of variance (ANOVA) to compare between more than two groups of numerical (parametric) data followed by post-hoc tukey test for multiple comparisons. For nonparametric data, Wilcoxon test was used for comparison between paired groups while Friedman test was used for multiple comparisons. Pvalue $<0.05$ was considered statistically significant.

\section{RESULTS}

\section{Light microscopic results}

\section{$H \& E$ stain}

\section{Control and NAC groups}

$\mathrm{H} \&$ E stained sections of the renal cortex of control and NAC rats revealed renal Malpighian corpuscles, proximal convoluted tubules (PCTs), distal convoluted tubules (DCTs) and collecting tubules (Fig. 1a). Malpighian corpuscles were comprised of Bowman's capsule and the glomerulus which was formed of a tuft of tortuous capillary loops lined by endothelial cells. Bowman's capsule showed a parietal and a visceral layer, separated by Bowman's space. The lining of the parietal layer was simple squamous epithelial cells with oval bulging nuclei. The visceral layer was lined by podocytes which had oval vesicular nuclei (Fig.1b). Most of the renal cortex was occupied by PCTs which had narrow lumen and were lined with simple cuboidal cells with central vesicular nuclei and acidophilic granular cytoplasm. These epithelial lining cells showed striated apical borders and indistinct lateral boundaries (Fig. 1a,b).

\section{Aceta-group}

The renal cortex of Aceta-group showed distortion of the glomeruli. Some of the glomeruli were shrunken and showed widening of Bowman's space (Fig. 2a). The parietal layer of Bowman's capsule was partially destroyed in some renal corpuscles (Fig. 2b). The lining cells of PCTs showed vacuolated cytoplasm (Fig. 2c). The lumen of some renal tubules appeared dilated (Fig. 2d) while others contained hyaline material and sloughed cells (Fig. 2e). Evident mononuclear cellular infiltration was also observed (Fig 2a,d,e).

\section{Aceta $+N A C$ group}

Examination of the renal cortex Aceta+NAC group demonstrated areas which are slightly similar to the control group (Fig. 3a,b). However, some of the glomeruli were still distorted and some of the PCTs appeared dilated (Fig. 3c). Other PCTs had vacuolated cytoplasm and acidophilic hyaline material in their lumen (Fig. 3c,d). Mononuclear cellular infiltration was also seen in the interstitium (Fig. 3d).

\section{Periodic Acid Schiff's stain}

PAS-stained sections of the renal cortex of control and NAC groups revealed strong PAS positive reaction in the basement membranes of the parietal layer of Bowman's capsule, glomerular capillaries and renal tubules. Strong PAS positive reaction was also observed in the brush border of the epithelial cells lining PCTs (Fig.4a).

In Aceta-group, strong PAS positive reaction was also detected in the basement membrane of glomerular capillaries and the parietal layer of Bowman's capsule (Fig. 4b). However, some renal corpuscles displayed PAS negative reaction in the parietal layer of the Bowman's capsules (Fig. 4c). Some of the PCTs lining cells showed interruptions in the positively stained basement membrane and brush borders (Fig. 4b). Sloughing of the brush borders of some of the PCTs lining cells into the lumen was also observed (Fig. 4c).

PAS stained sections of the renal cortex in Aceta+NAC group appeared more or less similar to control group, however, interruption of the PAS positive reaction was still seen in the brush borders of some of the PCTs lining cells (Fig. 4d).

\section{Mallory's trichrome stain}

Examination of Mallory-stained sections of the kidney in control and NAC groups showed minimal collagen fibers around Bowman's capsule and in between the glomerular capillaries (Fig. 5a,b). In Aceta-group, obvious deposition of collagen fibers was observed in the interstitium between the renal tubules and around the renal corpuscles (Fig. 5c,d). Mallory's trichrome stained sections of Aceta+NAC group displayed similar findings to those of control group (Fig. 5e). However, in some areas, deposition of collagen fibers was still seen around the renal corpuscles and in the interstitium around renal tubules (Fig.5f).

\section{Electron microscopic results}

\section{Podocytes, glomerular capillaries and glomerular basement membrane}

Electron microscopic examination of the ultrathin 
section of the control group revealed that the glomerular capillaries had fenestrated endothelial lining surrounded by the GBM. Podocytes showed folded nuclei and major processes extending parallel to GBM. Numerous minor processes extended from the major ones and passed perpendicular to the GBM to end by feet- like plates separated by filtration slits (Fig. 6a). The glomerular filtration barrier was formed of three layers; fenestrated capillary endothelium, trilaminar GBM and filtration slits between the minor processes of podocytes (Fig. 6b). In Aceta- group, TEM examination of the renal cortex revealed irregular thickening of GBM with loss of its trilaminar appearance. Glomerular capillaries were lined by bulging endothelial cells (Fig. 7a, b). In addition, the minor processes of podocytes appeared enlarged, fused causing obliteration of filtration slits (Fig. 7c). In Aceta+NAC group, GBM appeared mostly of regular thickness except for some thickened areas (Fig. 8a). The minor processes of the podocytes were separated by filtration slits and the glomerular capillaries were lined by fenestrated endothelium (Fig. 8b).

\section{Proximal convoluted tubules}

In control group, the cells lining the PCTs appeared cuboidal with central, rounded, vesicular nuclei. Their apical borders demonstrated numerous closely-packed microvilli projecting into the lumen. In addition, numerous tubular, longitudinally-oriented mitochondria were seen (Fig. 9a). On the other hand, in Aceta-group, lining cells of PCTs showed cytoplasmic vacuoles, increased density of the nucleus, irregular nuclear envelope and loss of the apical microvilli (Fig. 9b). Regarding Aceta+NAC group, the cells lining PCTs had vesicular nuclei, intact apical microvilli and basally-arranged mitochondria, however, some cytoplasmic vacuoles were still observed (Fig. 9c)

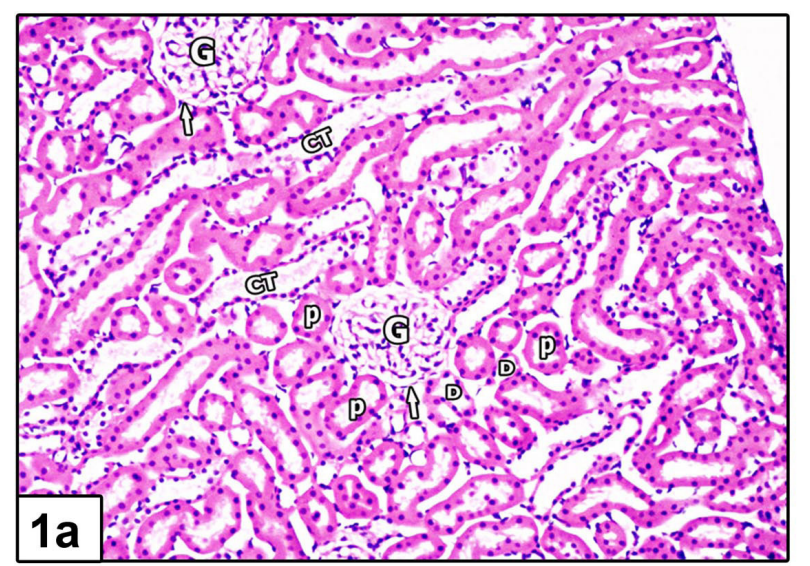

Fig. 1: Photomicrographs of the renal cortex in control group. (a) Showing glomeruli (G) surrounded by Bowman's capsule (arrows), PCTs (P), DCTs (D) and collecting tubules (CT). (b) A higher magnification of (a) showing a glomerulus (G), surrounded by Bowman's capsule (arrow head) and Bowman's space (arrow), PCTs (P) with narrow lumen, and acidophilic cytoplasm, DCT (D) having a wider lumen, acidophilic cytoplasm and collecting tubule (CT). The nuclei of podocytes (crossed arrows) appear oval and vesicular. (H \& $\mathrm{E} a \times 100 ; \mathrm{b} \times 400)$.

\section{Statistical results}

The mean corpuscular diameter was significantly smaller in Aceta-group (79.62 \pm 12.85 um) compared to control group (100.34 \pm 6.89 um). In Aceta+NAC group, MCD (96.14 \pm 3.92 um) was significantly larger compared to Aceta-group but still smaller than that in control group (Table 1). Regarding the percent of shrunken corpuscles and the area percent of collagenous fibers, they were significantly higher in Aceta-group $(21.74 \pm 2.16,6.71 \pm 0.53$ respectively) compared to control group (2.70 \pm 2.16 , $0.96 \pm 0.06)$. These percents were significantly lower in Aceta+NAC group $(9.18 \pm 0.61,1.70 \pm 0.11)$ compared to Aceta-group but still higher than control group (Tables 1). The area percent of PAS positive reaction was significantly higher in Aceta-group and Aceta+NAC group (38.91 \pm 0.60 , $42.02 \pm 0.76$ respectively) compared with control group $(36.98 \pm 0.32)$. This percent area was also significantly higher in Aceta+NAC group (42.02 \pm 0.76 ) in comparison with Aceta-group $(38.91 \pm 0.60)$ (Table 1). As regard to the thickness of GBM, its median range was significantly greater in Aceta-group (360.66nm) compared to control group (162.56 nm). In Aceta+NAC group, the median range of GBM thickness (185.18nm) showed a significant reduction in comparison to Aceta-group but remained greater than control group (Table 2).

The mean serum levels of BUN and creatinine were significantly higher in Aceta-group $(73.33 \pm 9.5,1.75 \pm 0.47$ $\mathrm{mg} / \mathrm{dl}$ respectively) compared to the control group (24.66 $\pm 4.13,0.575 \pm 0.1 \mathrm{mg} / \mathrm{dl})$. These levels were significantly reduced in Aceta+NAC group $(38.5 \pm 5.46,1.12 \pm 0.26$ $\mathrm{mg} / \mathrm{dl})$ compared to Aceta-group $(73.33 \pm 9.5,1.75 \pm 0.47$ $\mathrm{mg} / \mathrm{dl}$ ) but, remained significantly higher compared to the control group (Tables 3)

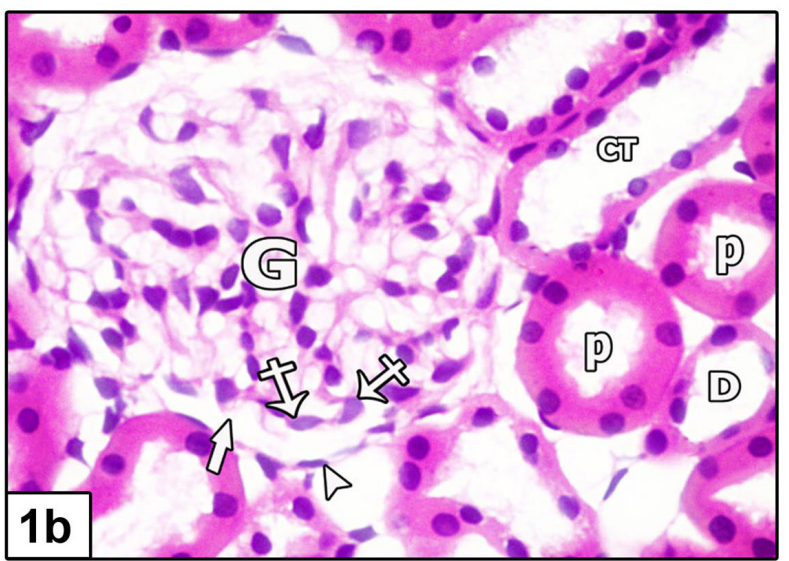



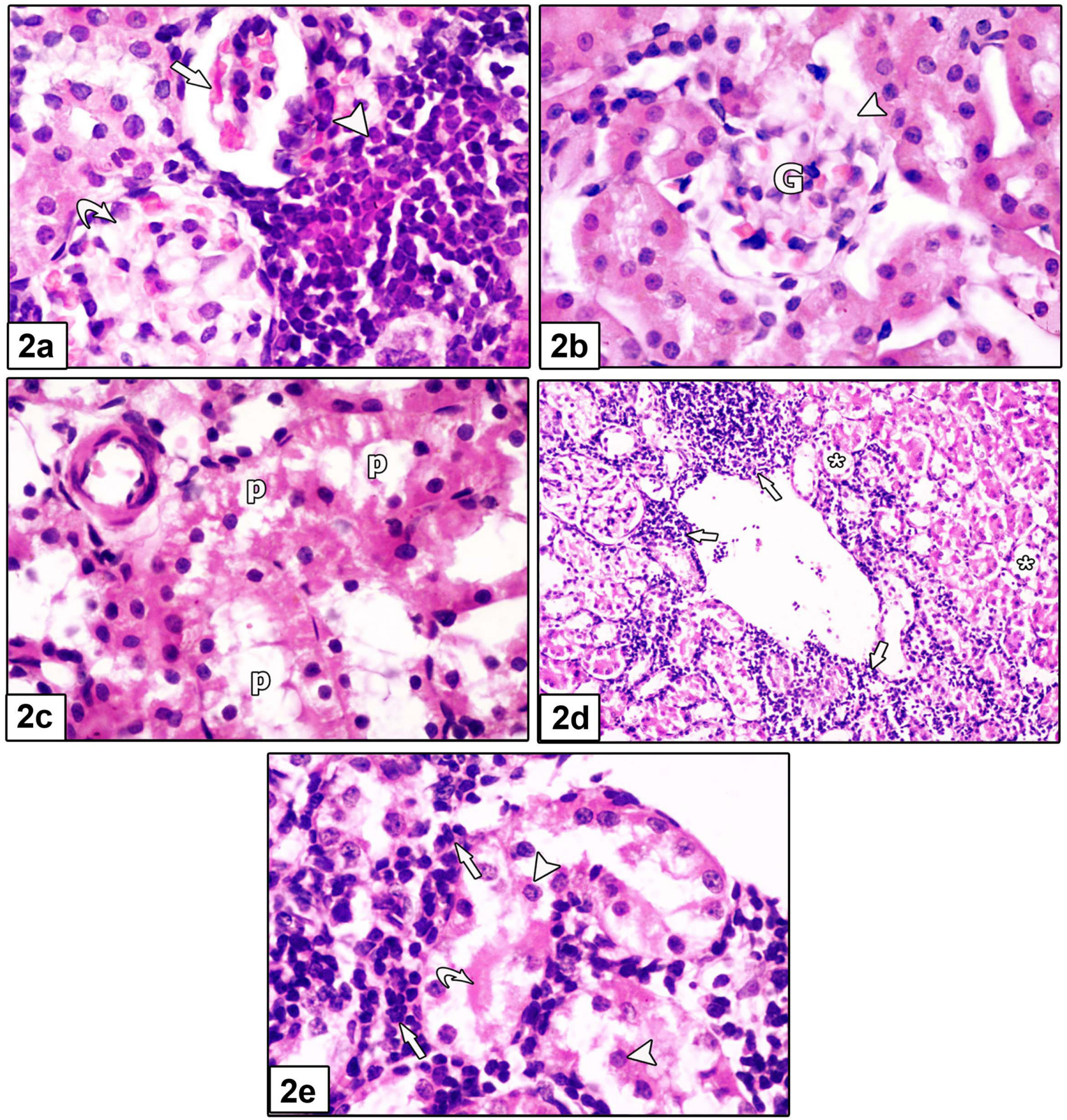

Fig. 2: Photomicrographs of the renal cortex in Aceta-group. (a) A glomerulus (curved arrow) and a shrunken one (arrow) are observed. Marked mononuclear cellular infiltration (arrow head) is also seen (b) A glomerulus $(G)$ surrounded by partially-destroyed Bowman's capsule (arrow head) is demonstrated. (c) The lining cells of PCTs (P) show vacuolated cytoplasm. (d) The tubules show luminal dilatations (asterisks). Heavy interstitial cellular infiltration (arrows) is observed (e) Desquamated cells (arrow heads) and homogenous acidophilic material (curved arrow) are found in the lumen of PCTs. Marked interstitial cellular infiltration (arrows) is also seen. (H \& E a,b,c,e× 400; $\mathrm{d} \times 100)$ 

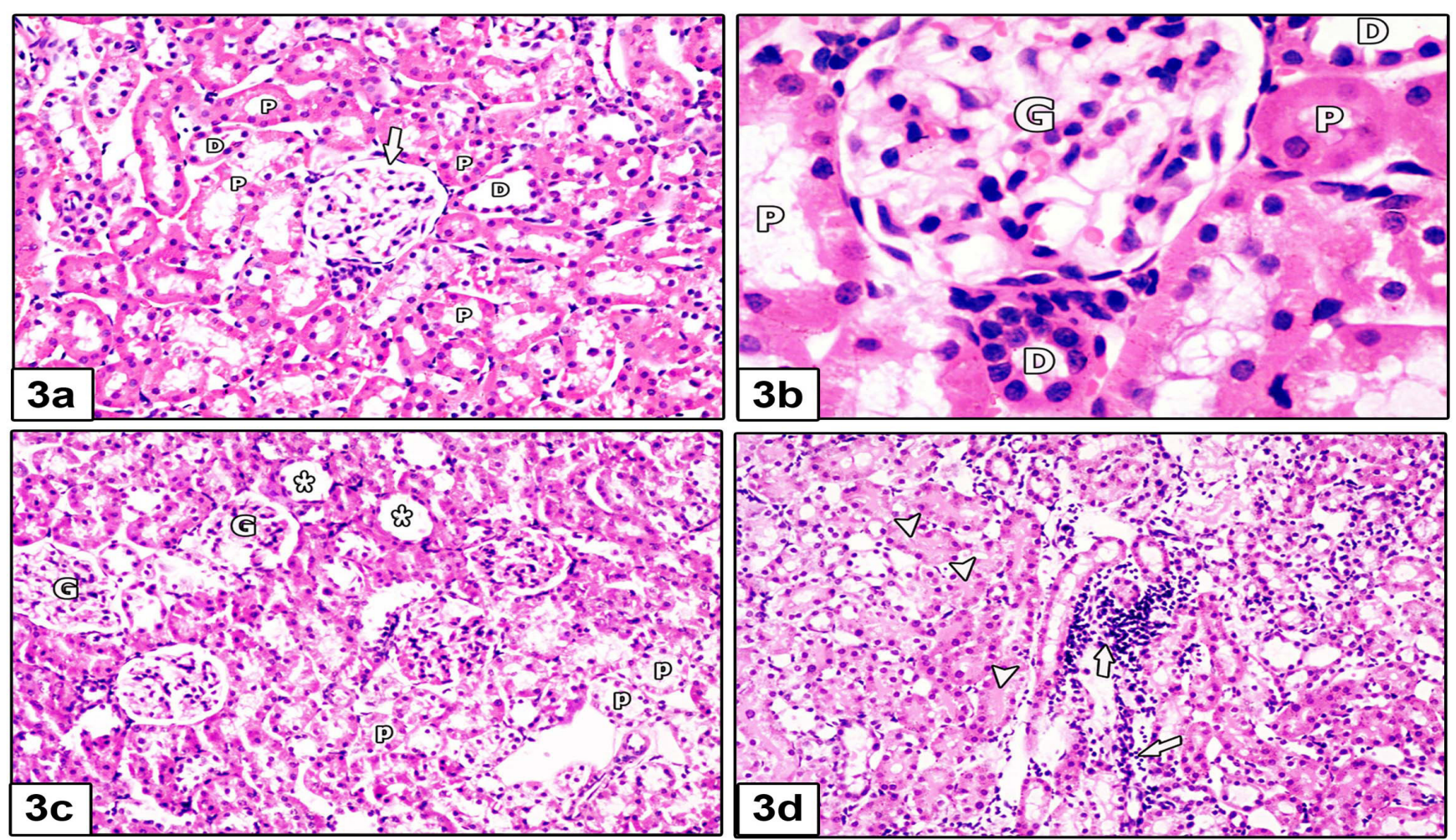

Fig. 3: Photomicrographs of the renal cortex in Aceta+NAC group. (a,b ) The renal corpuscle (arrow), PCTs (P) and DCTs (D) appear similar to those of the control. (c) Some distorted glomeruli (G), PCTs with vacuolated cytoplasm (P) and dilated tubules (asterisks) are observed. (d) Acidophilic hyaline material (arrow heads) is seen in the lumen of some tubules. Areas of cellular infiltration (arrows) are demonstrated. (H \& E a,c,d $\times 100 ; \mathrm{b} \times 400)$
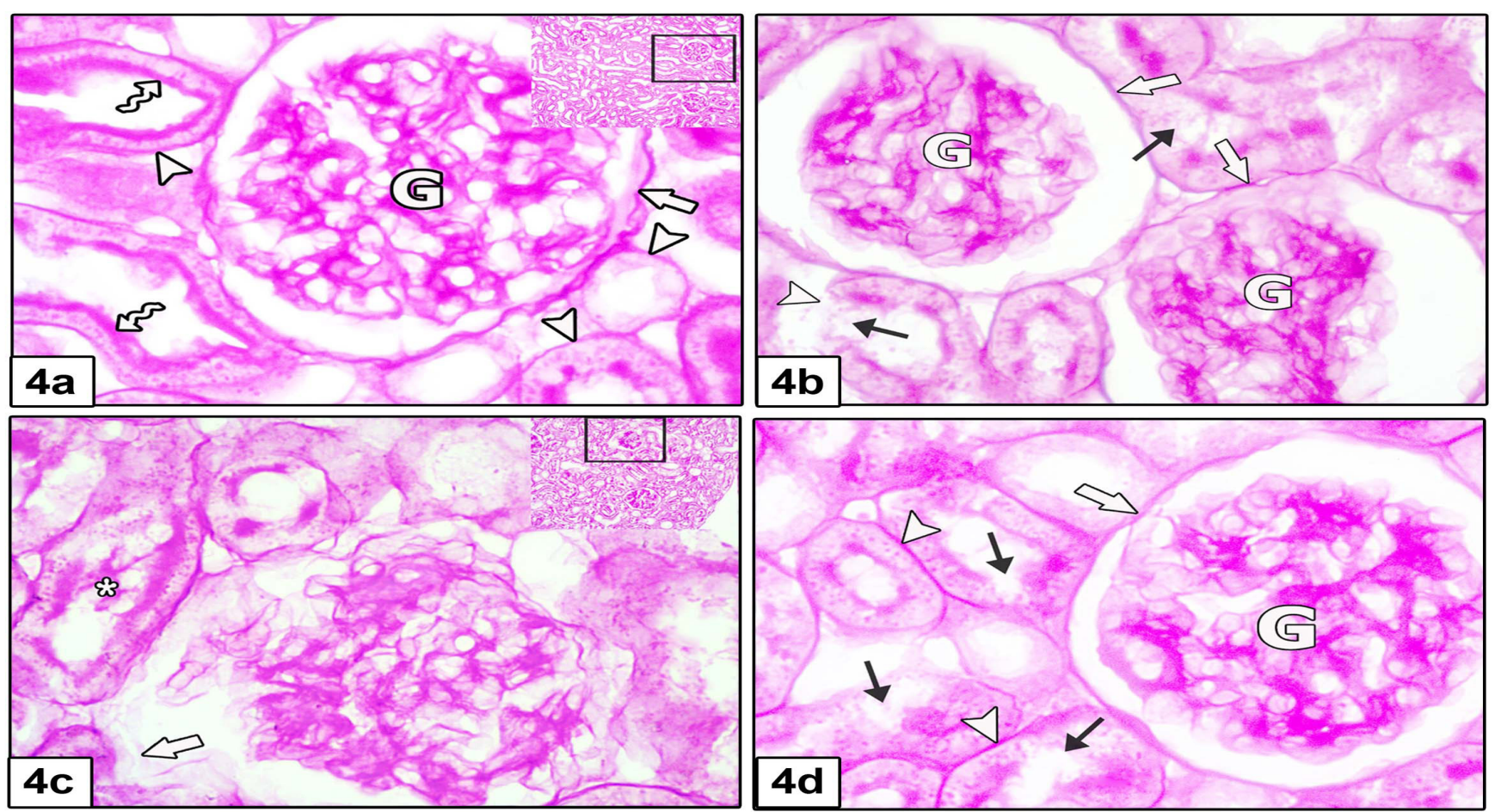

Fig. 4: Photomicrographs of PAS stained sections of the renal cortex in (a) control group; a higher magnification of the boxed area of the inset showing a strong PAS positive reaction in the basement membranes of the parietal layer of Bowman's capsule (arrow), the glomerular capillaries (G), and the renal tubules (arrow heads). The brush borders of PCTs (wavy arrows) also show a strong positive reaction. (b) Aceta-group; showing a strong PAS positive reaction in the basement membrane of glomerular capillaries $(\mathrm{G})$ and the parietal layer of Bowman's capsule (arrows). There is interruption in the PAS positive reaction in the brush border (black arrows) and in the basement membrane (arrow head) of some PCTs. (c) Aceta-group; a higher magnification of the boxed area of the inset showing PAS negative reaction in the basement membrane of the parietal layer of Bowman's capsule (arrow). There is positive reaction in the remnants of the sloughed brush border in the lumen of some PCTs (asterisk). (d) Aceta+NAC group; showing a strong PAS positive reaction in the basement membranes of the parietal layer of Bowman's capsule (arrow), glomerular capillaries (G), and renal tubules (arrow heads). Interrupted PAS-positive reaction is observed in the brush border of some PCTs (black arrows). (PAS $\times 400$, inset $\times 100$ ) 

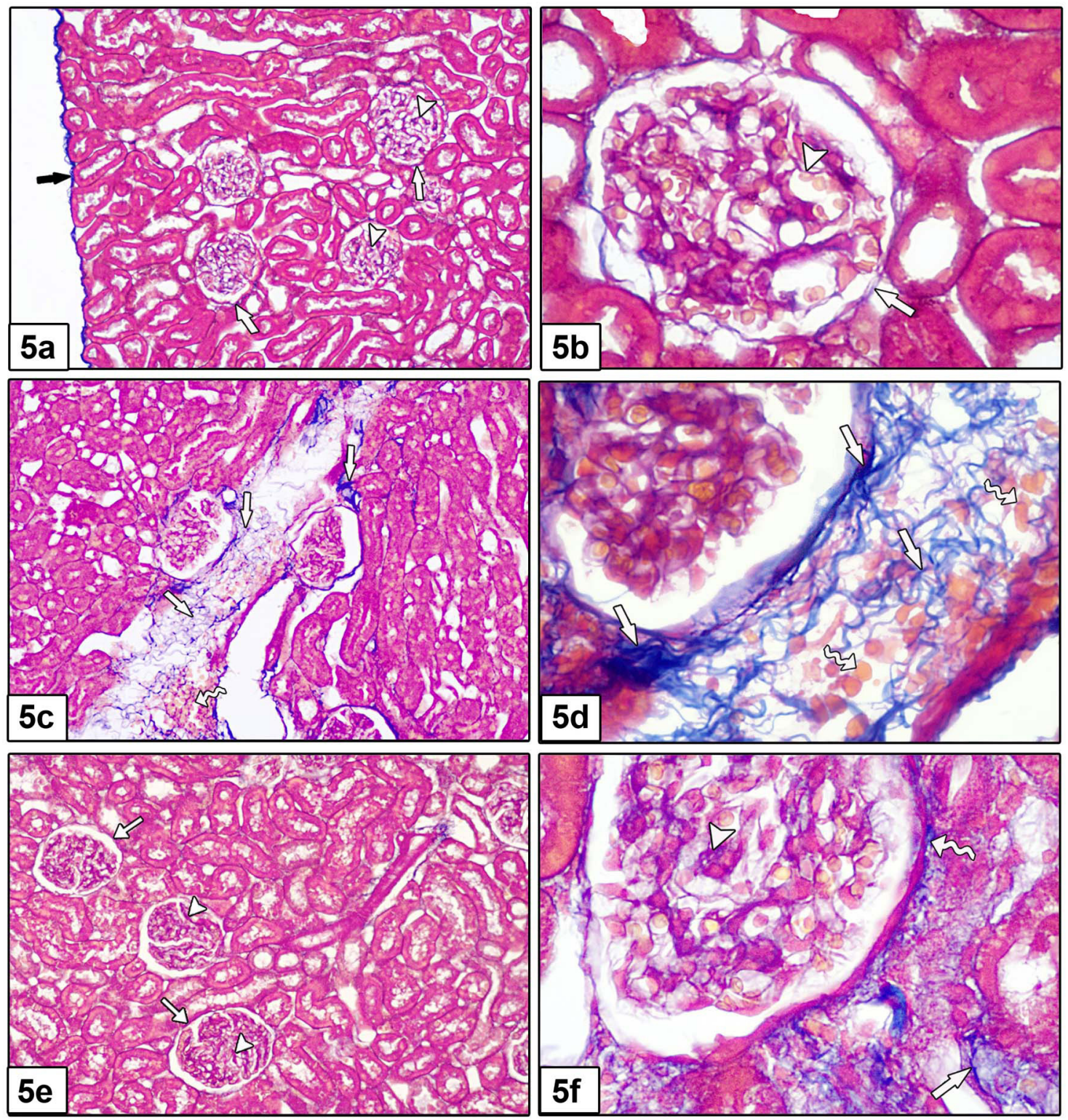

Fig. 5: Photomicrographs of Mallory's trichrome stained sections of the renal cortex in control group (a,b); showing collagen fibers in the renal capsule (black arrow). There are also minimal collagen fibers around Bowman's capsule (arrows) and in between the glomerular capillaries (arrow heads). Aceta-group (c,d); showing obvious deposition of collagen fibers in the interstitium between renal tubules and around the renal corpuscles (arrows). Interstitial hemorrhage (wavy arrows) is also noted. (e) Aceta+NAC group; showing little collagen fibers around Bowman's capsule (arrows) and in between the glomerular capillaries (arrow heads). (f) Aceta+NAC group; showing deposition of collagen fibers around the renal corpuscle (wavy arrow), in the interstitium (arrow) and in between the glomerular capillaries (arrow head). (Mallory's trichrome stain a,c,e $\times 100$; b,d,f× 400 ) 

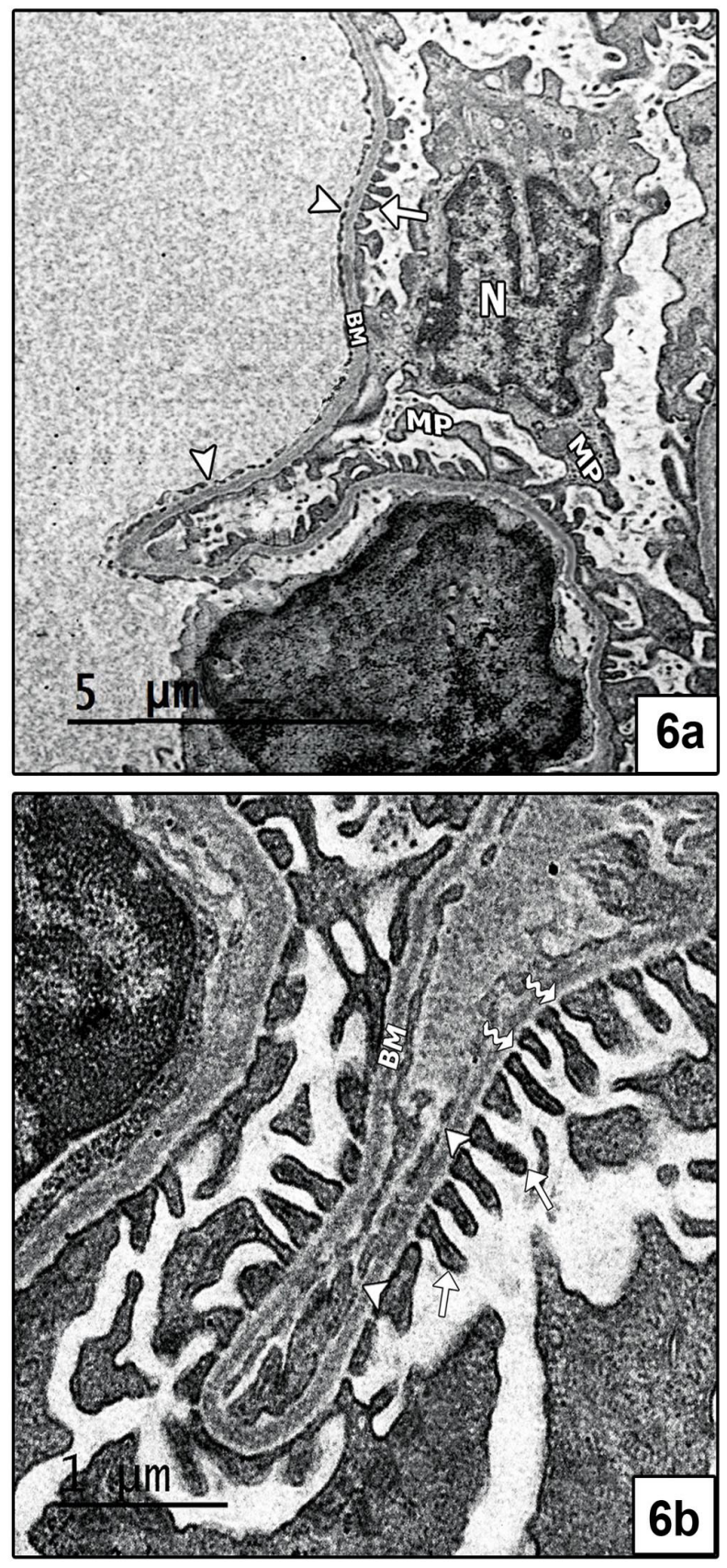

Fig. 6: Electron micrographs of the renal cortex in control group showing (a) a podocyte with a folded nucleus $(\mathrm{N})$. The cell body has major processes (MP) that give rise to minor ones (arrow) resting on the glomerular basement membrane (BM). Fenestrated endothelium (arrow heads), lining the glomerular capillaries, is also seen. (b) glomerular filtration barrier. It consists of three layers; fenestrated capillary endothelium (arrow heads), trilaminar glomerular basement membrane (BM) and filtration slits (wavy arrows) between the minor processes (arrows) of the podocyte. (TEM a $\times 25.500, \mathrm{~b} \times 68.000)$
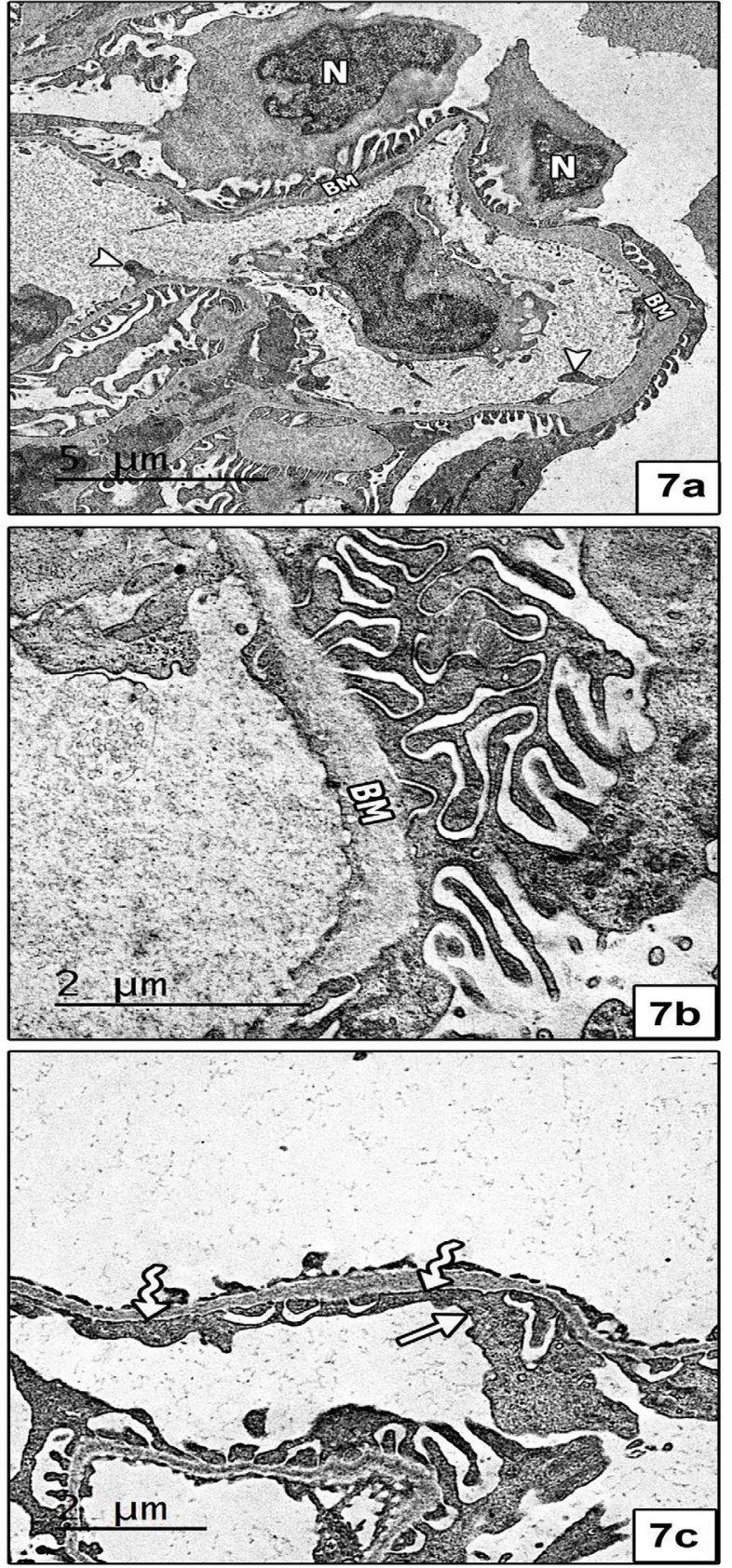

Fig. 7: Electron micrographs of the renal cortex in Aceta-group showing (a) two podocytes with folded nuclei $(\mathrm{N})$. Glomerular basement membrane (BM) appears irregularly thickened. Also, glomerular capillaries are lined by bulging endothelial cells (arrow heads). (b) apparent thickening and loss of trilaminar appearance of glomerular basement membrane (BM). (c) enlarged fused minor processes (arrow) of podocytes with obliteration of filtration slits (wavy arrows). (TEM a $\times 17.000 ; \mathrm{b} \times 51.000 ; \mathrm{c} \times 34.000)$ 

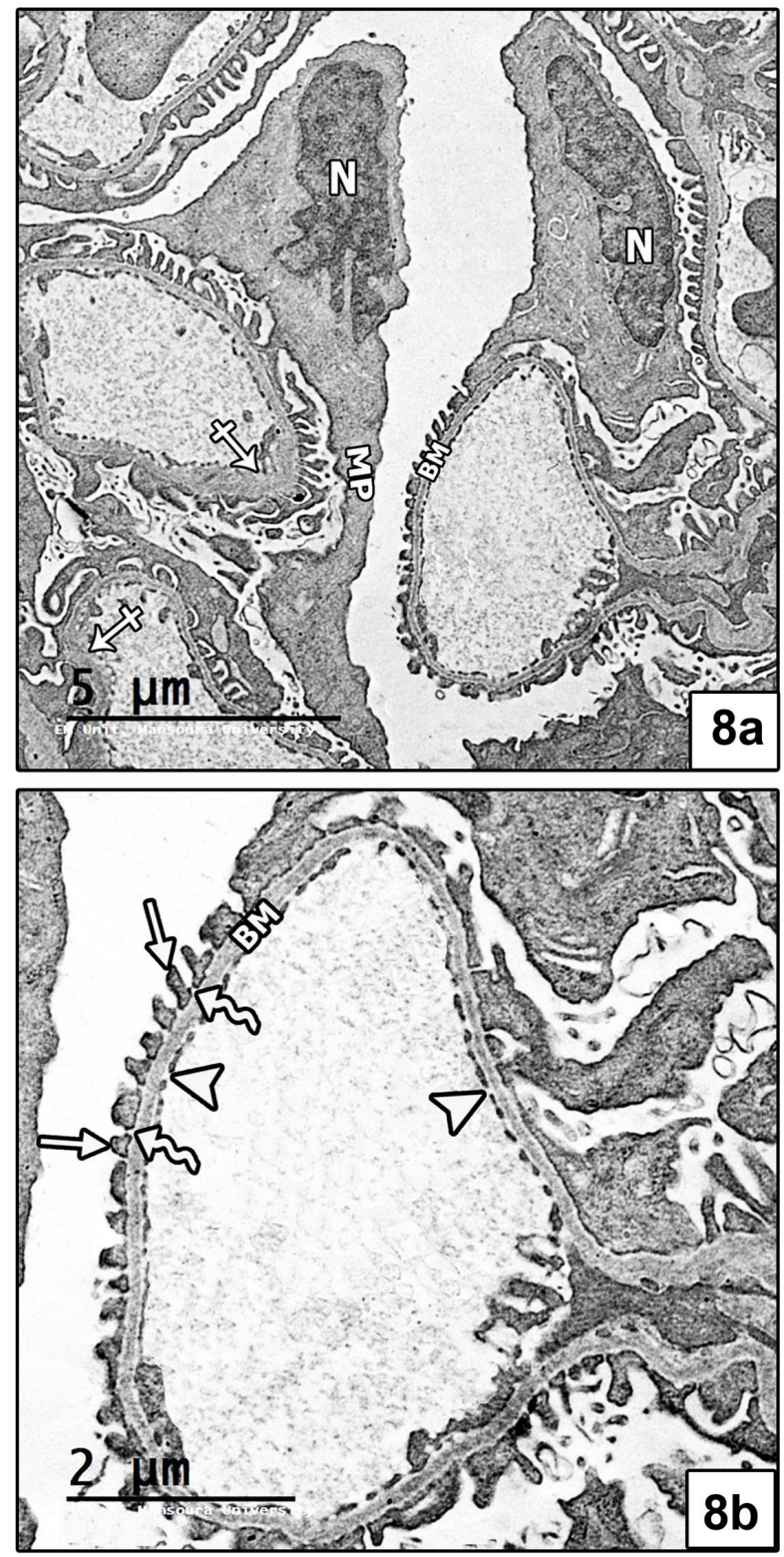

Fig. 8: Electron micrographs of the renal cortex in Aceta+NAC showing (a) two podocytes with folded nuclei $(\mathrm{N})$. One of them has a major process (MP). Glomerular basement membrane (BM) appears mostly of regular thickness except for some thickened areas (crossed arrows). (b) regular glomerular basement membrane (BM). Minor processes (arrows) are seen separated by filtration slits (wavy arrows). Glomerular capillaries are lined by fenestrated endothelium (arrow heads). (TEM a $\times 20.400$; $\mathrm{b} \times 42.500)$
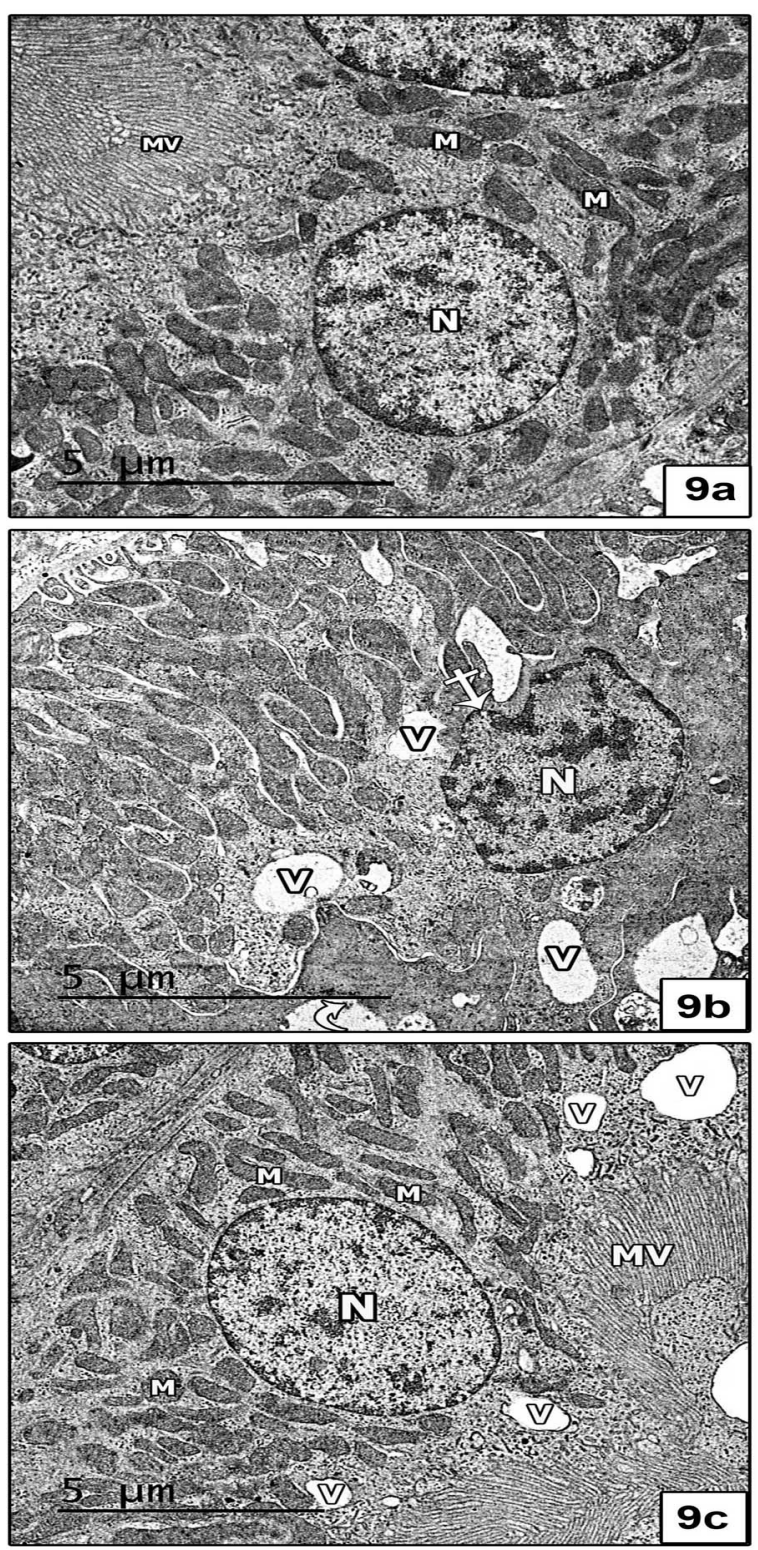

Fig. 9: Electron micrographs of the renal cortex showing PCT lining cells in (a) control group; the cells have rounded central vesicular nuclei $(\mathrm{N})$, mitochondria (M), and apical long microvilli (MV). (b) Aceta-group; the cells show cytoplasmic vacuoles (V), a dense nucleus (N) with irregular nuclear envelope (crossed arrow) and loss of apical microvilli (curved arrow). (c) Aceta+NAC group; the cells contain vesicular nuclei $(\mathrm{N})$ and basally-arranged mitochondria (M). Apical microvilli (MV) are also seen. Cytoplasm contains some vacuoles (V). (TEM a $\times 25.500$; b X 25.500; $\mathrm{c} \times 20.400)$ 
Yaseen et. al.,

Table 1: Mean corpuscular diameter (um), percent of shrunken corpuscles, percent area of collagenous fibers and percent area of PAS positive reaction in the studied groups.

\begin{tabular}{|c|c|c|c|c|c|c|}
\hline & & Control Group & NAC Group & Aceta. Group & Aceta.+ NAC Group & $\begin{array}{c}\text { ANOVA } \\
P \text { value }\end{array}$ \\
\hline & Mean & 100.342 & 100.505 & 79.622 & 96.140 & \\
\hline & $\pm \mathrm{SD}$ & 6.895 & 7.013 & 12.856 & 3.9257 & \\
\hline \multirow[t]{5}{*}{ MCD } & $\mathrm{P} 1$ & & 1.000 & $<0.001$ & 0.059 & $<0.001$ \\
\hline & $\mathrm{P} 2$ & & & $<0.001$ & 0.046 & \\
\hline & P3 & & & & $<0.001$ & \\
\hline & Mean & 2.7030 & 2.6520 & 21.7440 & 9.1810 & \\
\hline & $\pm \mathrm{SD}$ & .25816 & .29302 & 2.161 & .61578 & \\
\hline \multirow[t]{5}{*}{$\%$ of shrunken corpuscles } & $\mathrm{P} 1$ & & 1.00 & $<0.001$ & $<0.001$ & $<0.001$ \\
\hline & $\mathrm{P} 2$ & & & $<0.001$ & $<0.001$ & \\
\hline & P3 & & & & $<0.001$ & \\
\hline & Mean & .96340 & 1.02060 & 6.71420 & 1.70740 & \\
\hline & $\pm \mathrm{SD}$ & .065962 & .150467 & .530889 & .111916 & \\
\hline \multirow[t]{5}{*}{$\%$ area of collagenous fibers } & $\mathrm{P} 1$ & & .969 & $<0.001$ & $<0.001$ & $<0.001$ \\
\hline & $\mathrm{P} 2$ & & & $<0.001$ & $<0.001$ & \\
\hline & P3 & & & & $<0.001$ & \\
\hline & Mean & 36.9844 & 36.6680 & 38.9185 & 42.0265 & \\
\hline & $\pm \mathrm{SD}$ & .32869 & .65527 & 60997 & .76841 & \\
\hline \multirow[t]{3}{*}{$\%$ area of PAS positive reaction } & $\mathrm{P} 1$ & & .658 & $<0.001$ & $<0.001$ & $<0.001$ \\
\hline & $\mathrm{P} 2$ & & & $<0.001$ & $<0.001$ & \\
\hline & P3 & & & & $<0.001$ & \\
\hline
\end{tabular}

SD: standard deviation. P: Probability. Significance $\leq 0.05$

Test used: One way ANOVA test followed by post-hoc tukey.

High significance $<0.001$

P1: Significance relative to Control group.

P2: Significance relative to NAC group.

P3: Significance relative to Aceta-group.

Table 2: Thickness of glomerular basement membrane (nm) in the studied groups

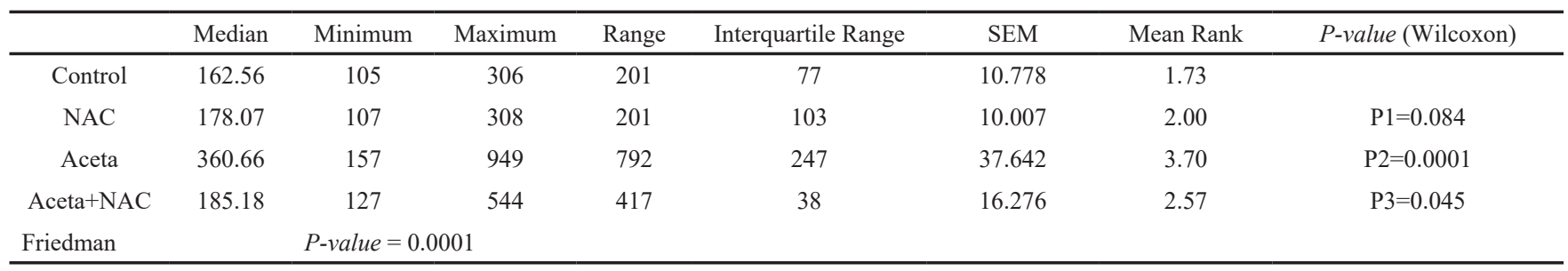

Test used: Wilcoxon test for comparison between paired groups, Friedman test for multiple comparisons.

P1: Compare between NAC and Control group.

P2: Compare between Aceta and Control group.

P3: Compare between Aceta+NAC and control group. 
Table 3: Mean serum levels of BUN $(\mathrm{mg} / \mathrm{dl})$ and creatinine $(\mathrm{mg} / \mathrm{dl})$ in the studied groups.

\begin{tabular}{|c|c|c|c|c|c|c|}
\hline & & Control Group & NAC Group & Aceta. Group & Aceta.+ NAC Group & $\begin{array}{c}\text { ANOVA } \\
P \text { value }\end{array}$ \\
\hline & Mean & 24.66 & 24.16 & 73.33 & 38.5 & \\
\hline & $\pm \mathrm{SD}$ & 4.13 & 3.6 & 9.5 & 5.46 & \\
\hline \multirow[t]{5}{*}{ BUN } & $\mathrm{P} 1$ & & 0.99 & $<0.001$ & 0.004 & $<0.001$ \\
\hline & P2 & & & $<0.001$ & 0.003 & \\
\hline & P3 & & & & $<0.001$ & \\
\hline & Mean & 0.575 & 0.60 & 1.750 & 1.123 & \\
\hline & $\pm \mathrm{SD}$ & 0.100 & 0.106 & 0.473 & 0.266 & \\
\hline \multirow[t]{3}{*}{ Serum creatinine } & $\mathrm{P} 1$ & & 0.99 & $<0.001$ & 0.015 & $<0.001$ \\
\hline & P2 & & & $<0.001$ & 0.021 & \\
\hline & P3 & & & & 0.005 & \\
\hline
\end{tabular}

SD: standard deviation. P: Probability. Significance $\leq 0.05$

Test used: One way ANOVA test followed by post-hoc tukey.

P1: Significance relative to Control group.

P2: Significance relative to NAC group.

P3: Significance relative to Aceta-group.

\section{DISCUSSION}

The present study demonstrated that chronic administration of APAP resulted in structural changes in the renal cortex that primarily involved PCTs with some affection of the renal corpuscles. Previous workers reported that APAP renal toxicity was presumably restricted to the renal cortex, especially PCTs, as it required CYP-450 mediated bioactivation that was almost localized in this part of the kidney ${ }^{[22,23,24]}$. However, some authors ${ }^{[25]}$ reported that the ingestion of chronic low dose of APAP for 30 days did not produce gross changes in the renal histology.

All renal histological changes observed in Aceta-group could be attributed to glutathione (GSH) depletion. It has been reported that APAP administration leads to reduction of GSH which is used for the detoxification of APAP metabolites, especially N-acetyl-p-benzoquinoneimine (NAPQI ${ }^{[26]}$. GSH depletion is only one of a cascade of intracellular events which include mitochondrial oxidative stress, activation of stress proteins, gene transcription mediators, and generation of reactive oxygen species (ROS) and reactive nitrogen species. Subsequent activation of caspases and lysosomal enzymes initiates apoptosis, or programmed cell death ${ }^{[2,27]}$.

In the current work, Aceta-group displayed some degenerative changes in the renal corpuscles manifested by shrinkage of some glomeruli in addition to partial destruction of some Bowman's capsules. These changes might be attributed to oxidative stress and the toxic effect of APAP metabolites and are in parallel with those of ${ }^{[28,29]}$.

Ultrastructurally, irregular thickening of GBM, enlargement and fusion of the minor processes of podocytes were detected in Aceta-group. This might be attributed to the accumulation of ROS which attack GBM and degrade its matrix components through activation of proteases and reduction of proteoglycan synthesis. It has been suggested that fusion of the minor processes might be due to direct injury to the podocytic cytoskeleton by ROS or might be secondary to GBM thickening, as a compensatory mechanism for the increased permeability of the glomerular capillaries ${ }^{[30]}$. Swelling of some of the endothelial cells, lining the glomerular capillaries was also observed in this group. In accordance, previous studies ${ }^{[31,32]}$ reported that ROS might cause deleterious effects on the glomerular endothelium in chronic kidney diseases which subsequently lead to endothelial dysfunction.

In Aceta-group, PCTs showed degenerative changes. This was represented by vacuolation of the cytoplasm, and presence of acidophilic hyaline material, desquamated cells in the lumen. These changes might be attributed to production of large amounts of APAP metabolite, especially NAPQI, which reached the kidney for excretion. They might cause vascular damage and tubular ischemic changes, which progress to acute tubular necrosis ${ }^{[10,13,33]}$. In this respect, some authors ${ }^{[34]}$ added that oxidative stress and insufficient amount of renal GSH also might play an important role in APAP tubular necrosis.

The presence of hyaline acidophilic material in the lumen of PCTs might result from detachment and hyalinization of the degenerated lining cells. This was mostly due to cytoskeletal alterations and impaired intercellular adhesion caused by ROS. They might destabilize cytoskeletal proteins and proteins responsible for adhesion between cells and extracellular matrix such as integrin. In addition, lipid peroxidation might lead to damage of cell membranes with subsequent sloughing of the cytoplasmic components into the lumen. The accumulation of cellular debris in the lumen caused partial or total tubular obstruction with subsequent increased hydrostatic pressure inside, leading 
to dilatation of some of tubules. These findings come in agreement with ${ }^{[35,36]}$.

In the current study, distortion and loss of apical brush border of some PCTs was demonstrated in PAS stained sections. This was verified by EM which revealed marked disruption of the apical microvilli. This was most probably due to lipid peroxidation of the cell membrane of those cells, leading to impaired active absorptive and excretory capacity of PCTs. These results are in parallel with studies of ${ }^{[12,37]}$.

The lining cells of PCTs showed ultrastructural features of apoptotic cell death represented by heterochromatic nuclei with irregular outline, and cytoplasmic vacuoles. As previously reported, apoptosis is characterized by invagination of the nuclear membrane, chromatin condensation, densely packed mitochondria, and electron dense vesicles ${ }^{[38]}$. Furthermore, previous workers ${ }^{[39]}$ stated that lipid peroxidation might play a role in the molecular and cellular damage by destroying the functional integrity of the cell membrane and if the damage was severe, cell death would occur.

The inflammatory cellular infiltration was evident in the renal interstitium of Aceta- group. This might be due to oxidative stress which triggered a secondary inflammatory cascade associated with cytokine release. Previous workers $^{[3,40,41]}$ stated that pro-inflammatory cytokines as TNF- $\alpha$, IL- $1 \beta$ and IL- 6 were prominently described in APAP-induced hepato-renal toxicity.

A significant increase in the percent area of collagenous fibers was also noticed in Mallory trichrome- stained sections of Aceta-group. Similar findings were described by $^{[42,43]}$ who stated that the release of cytokines, such as transforming growth factor $\beta-1$, leads to activation of myofibroblasts which secrete protease inhibitors that might result in increased synthesis and impaired turnover of extracellular matrix proteins and the initiation of fibrosis.

Regarding biochemical findings, Aceta-group showed significant increases in the serum levels of BUN and creatinine which are considered to be the most commonly used nephrotoxicity biomarkers ${ }^{[44]}$. Increased BUN level might be explained by the accumulation of urea that occurred as a result of decreased rate of clearance, whereas the elevation in the plasma creatinine might be the result of endogenous breakdown of tissue creatine, in case of damage to the functioning nephrons. These biochemical findings are parallel with the histological and ultrastructural degenerative changes recorded in this group and come in accordance with those of ${ }^{[33,41,45]}$.

In Aceta+NAC group, partial improvement in the renal histoarchitecture and ultrastructure was demonstrated, however, mononuclear cellular infiltration and deposition of collagen fibers were still observed. These changes were reflected on the serum levels of BUN and creatinine which showed significant reductions compared to Acetagroup. These findings are consistent with ${ }^{[46]}$ who found that NAC significantly lowered the number of infiltrating lymphocytes, macrophages, and monocytes both in the glomeruli and in the interstitium in chronic kidney diseases. On contrary, other authors ${ }^{[7,13,47]}$ mentioned that NAC was ineffective in the treatment of APAP nephrotoxicity. However, other researchers ${ }^{[39]}$ found that NAC alone was unable to protect against APAP nephrotoxicity and when combined with ozone therapy, they played a renal protective role. This controversy might be due to the difference in the dose of NAC or the duration of treatment.

The beneficial effect of NAC as a nephroprotective agent against APAP toxicity and many other nephrotoxic agents such as Ifosfamide ${ }^{[48,49]}$, cisplatin ${ }^{[50]}$ and heavy metals ${ }^{[51]}$ was previously reported. Furthermore, NAC has a protective effect on the kidney in ischemia/reperfusion injury and contrast-induced nephropathy ${ }^{[52,53]}$. In addition, NAC is beneficial as an antidote in the management of APAP hepatotoxicity ${ }^{[54,55]}$.

The protective role of NAC in APAP nephrotoxicity may be attributed to its antioxidant capacity. $\mathrm{N}$-acetylcysteine exhibits direct and indirect antioxidant properties. Its direct effect is achieved through its free SH group that is capable of neutralizing ROS. In addition, it exerts an indirect antioxidant effect through stimulating GSH synthesis and promoting detoxification ${ }^{[6,57]}$. GSH is a critical intracellular antioxidant in human cells ${ }^{[58,59]}$. N-acetylcysteine provides cysteine for the replenishment; maintenance of hepatic GSH stores (a GSH precursor) and enhances the sulfation pathway of elimination. It may, directly, reduce NAPQI back to APAP and also increases glutathione-S transferase activity. Previous reports ${ }^{[9,60]}$ postulated that NAC enhances intracellular biosynthesis of GSH, replenishing its stores which is essential for overcoming the harmful effects of toxic agents.

Prior studies ${ }^{[9,57]}$ added that NAC had several antiinflammatory properties as inhibiting expression and release of pro-inflammatory cytokines and decreasing neutrophil infiltration through increasing the blood flow in the microcirculation and the oxygen transport to the tissues in APAP intoxication

\section{CONCLUSION}

N-acetylcysteine could attenuate histological and biochemical changes induced by chronic usage of acetaminophen in the rat renal cortex.

\section{CONFLICTS OF INTEREST}

There is no conflict of interest to declare.

\section{REFERENCES}

1. Ennis ZN, Dideriksen D, Vaegter HB, Handberg G, Pottegard A. Acetaminophen for chronic Pain: a systematic review on efficacy. Basic Clin. Pharmacol. Toxicol. 2015;118 (3): 184-189.

2. Hodgman MJ, Garrard AR. A review of acetaminophen poisoning. Crit. Care Clin. 2012; 28 (4): 499-516. 
3. Salih ND, Hazir NM, Abo Hamid MH. The effect of mulberry (morus sp.) tea supplement on acetaminophen induced renal failure in rats. World J. Pharm. Pharm. Sci. 2015; 4 (4): 111-125.

4. X, Wang L, Huang J, Lv H, Deng X, Ci X. Pterostilbene Reduces Acetaminophen-Induced Liver Injury by Activating the Nrf2 Antioxidative Defense System via the AMPK/Akt/GSK3 $\beta$ Pathway. Cell Physiol Biochem 2018; 49:19431958. doi: 10.1159/000493655.

5. Palipane N, Jiad E, de Wolff JF. Paracetamol overdose. Br. J. Hosp. Med. 2015; 76 (2): C18-22.

6. Kelkar M, Cleves MA, Foster HR, Hogan WR, James LP, Martin BC. Acute and chronic acetaminophen use and renal disease: a casecontrol study using pharmacy and medical claims. J. Manag. Care Pharm. 2012; 18 (3): 234-246.

7. Mazer M, Perron J. Acetaminophen-induced nephrotoxicity: pathophysiology, clinical manifestations, and management. J. Med. Toxicol. 2008; 4 (1): 2-6.

8. Aruoma OI., Halliwell B, Hoey BM, Butler J. The antioxidant action of $\mathrm{N}$-acetylcysteine: its reaction with hydrogen peroxide, hydroxyl radical, superoxide, and hypochlorous acid. Free Radic. Biol. Med. 1989; 6 (6): 593-597.

9. Tahia H. Saleem, Nagwa Abo El-Maali, Mohammed H. Hassan, et al. "Comparative Protective Effects of N-Acetylcysteine, N-Acetyl Methionine, and N-Acetyl Glucosamine against Paracetamol and Phenacetin Therapeutic Doses-Induced Hepatotoxicity in Rats," International Journal of Hepatology, vol. 2018, Article ID 7603437, 8 pages, 2018. https://doi.org/10.1155/2018/7603437.

10. Kandis H, Erkan ME, Yildirim U, Gunes H, Erbas $\mathrm{M}$, Yildirim HA, et al. Comparison of the effects of $\mathrm{N}$-acetyl cysteine and erdosteine in rats with renal injury caused by paracetamol intoxication. Hum. Exp. Toxicol. 2010; 30 (9): 1350-1358.

11. Yousef MI, Omar SA, El-Guendi MI, Abdelmegid, LA. Potential protective effects of quercetin and curcumin on paracetamol-induced histological changes, oxidative stress, impaired liver and kidney functions and haematotoxicity in rat. Food Chem. Toxicol. 2010; 48 (11): 3246-3261.

12. Abraham P. Vitamin $\mathrm{C}$ may be beneficial in the prevention of paracetamol-induced renal damage. Clin. Exp. Nephrol. 2005; 9 (1): 24-30.

13. Cekmen M, Ilbey Y O, Ozbek E, Simsek A, Somay A, Ersoz C. Curcumin prevents oxidative renal damage induced by acetaminophen in rats. Food Chem. Toxicol. 2009; 47 (7): 1480-1484.
14. Kondo K, Yamada N, Suzuki Y, Toyoda K, Hashimoto T, Takahashi A, Kobayashi A, Shoda T, Kuno H, Sugai S. Enhancement of acetaminopheninduced chronic hepatotoxicity in restricted fed rats: a nonclinical approach to acetaminopheninduced chronic hepatotoxicity in susceptible patients. J. Toxicol. Sci. 2012; 37 (5): 911-929.

15. Vogler GA. Anesthesia and Analgesia. In: Mark A. Suckow, Steven H. Weisbroth and Craig L. Franklin (editors), The Laboratory Rat (Second Edition) ISBN. 2006; 978-0-12-074903-4 pp 627-664.

16. Bancroft JD, Layton C. The Hematoxylin and Eosin. In Suvarna, S. K., Layton, C. \& Bancroft, J. D. (Eds.), Bancroft's Theory and Practice of Histological Techniques (7th Ed.) Philadelphia, USA: Churchill Livingstone /Elsevier. 2013; PP: 173-186.

17. Totty BA. Mucins. In: Bancroft JD, Gamble M, (editors), Theory and practice of histological techniques. 5th ed. New York: Churchill Livingstone. 2002; p.175.

18. Kiernan JA. Histological and Histochemical Methods: Theory and Practice 4th Ed. Bloxham, UK: Scion. 2008; PP: 190-213.

19. Woods, A.E., Stirling, JW. Electron microscopy. In: Bancroft, J.D., Gamble, M. (Eds.), Theory and Practice of Histological Techniques, 6th ed. Churchill Livingstone Elsevier, Edinburgh. 2008; pp. 601-636.

20. Marsh WH, Fingerhut B, Miller H. Automated and manual direct methods for the determination of blood urea. Clin. Chem. 1965; 11: 624-627.

21. Spencer K. Analytical reviews in clinical biochemistry: the estimation of creatinine. Ann. Clin. Biochem. 1986; 23 ( Pt 1): 1-25.

22. Isik B, Bayrak R, Akcay A, Sogut S. Erdosteine against acetaminophen induced renal toxicity. Mol. Cell Biochem 2006; 287 (1-2): 185-191.

23. Refaat SH, Mady AA. Vitamin A against the acetaminophen- induced toxicity in the renal cortex of albino rats. Egypt. J. Histol. 2008; 31 (2): 321-323.

24. Vrbova M, Rousarova E, Bruckova L, Cesla P, Rousar T. Characterization of acetaminophen toxicity in human kidney HK-2 cells. Physiol. Res. 2016; 65 (4): 627-635.

25. Ahmed MH, Ashton N, Balment RJ. Renal function in a rat model of analgesic nephropathy: effect of chloroquine. J. Pharmacol. Exp. Ther. 2003; 305 (1): 123-130. 
26. Ben-Shachar R, Chen Y, Luo S, Hartman C, Reed M, Nijhout HF. The biochemistry of acetaminophen hepatotoxicity and rescue: a mathematical model. Theor. Biol. Med. Model. 2012; 9: 55.

27. Abdelmegeed MA, Moon KH, Chen C, Gonzalez FJ, Song BJ. Role of cytochrome P450 2E1 in protein nitration and ubiquitin-mediated degradation during acetaminophen toxicity. Biochem. Pharmacol. 2010; 79 (1): 57-66.

28. Bektur NE, Sahin E, Baycu C, Unver G. Protective effects of silymarin against acetaminopheninduced hepatotoxicity and nephrotoxicity in mice. Toxicol. Ind. Health. 2016; 32 (4): 589-600.

29. Naggayi M, Mukiibi N, Iliya E. The protective effects of aqueous extract of Carica papaya seeds in paracetamol induced nephrotoxicity in male wistar rats. Afr. Health Sci. 2015; 15 (2): 598-605.

30. Rateb A, Abdel-Hafez AM. Effect of Nigella sativa oil on paracetamol-induced renal cortical damage in rats: light and electron microscopic study. Egypt. J. Histo. 2013; 36: 127-138.

31. Jaimes EA, Hua P, Tian RX, Raij L. Human glomerular endothelium: interplay among glucose, free fatty acids, angiotensin II, and oxidative stress. Am. J. Physiol. Renal Physiol. 2010; 298 (1): F125-132.

32. Singh A, Ramnath RD, Foster RR, Wylie EC, Friden V, Dasgupta I et al. Reactive oxygen species modulate the barrier function of the human glomerular endothelial glycocalyx. PLoS One. 2013; 8 (2): e55852.

33. Paul S, Islam MA, Tanvir EM, Ahmed R, Das $\mathrm{S}$, Rumpa NE et al. Satkara (Citrus macroptera) fruit protects against acetaminophen-induced hepatorenal toxicity in rats. Evid. Based Complement. Alternat. Med., 2016: 9470954.

34. Gupta G, Chellappan DK, Kikuchi IS, Pinto TJA, Pabreja K, Agrawal M, Singh Y, Tiwari J, Dua K.J. Nephrotoxicity in Rats Exposed to Paracetamol: The Protective Role of Moralbosteroid, a Steroidal Glycoside. Environ Pathol Toxicol Oncol. 2017; 36(2):113-119.

35. Dhibi S, Mbarki S, Elfeki A, Hfaiedh N. Eucalyptus globulus extract protects upon acetaminopheninduced kidney damages in male rat. Bosn. J. Basic Med. Sci. 2014; 14 (2): 99-104.

36. Murad HA, Habib H, Kamel Y, Alsayed S, Shakweer M, Elshal M. Thearubigins protect against acetaminophen-induced hepatic and renal injury in mice: biochemical, histopathological, immunohistochemical, and flow cytometry study. Drug Chem. Toxicol. 2016; 39 (2): 190-198.
37. Aycan IO, Tokgoz O, Tufek A, Alabalik U, Evliyaoglu O, Turgut $\mathrm{H}$ et al. The use of thymoquinone in nephrotoxicity related to acetaminophen. Int. J. Surg. 2015; 13: 33-37.

38. Tiso M, Gangemi R, Bargellesi Severi A, Pizzolitto S, Fabbi M, Risso A. Spontaneous apoptosis in human thymocytes. Am. J. Pathol. 1995; 147 (2): 434-444.

39. Ucar F, Taslipinar MY, Alp BF, Aydin I, Aydin FN, Agilli $\mathrm{M}$ et al. The effects of $\mathrm{N}$-acetylcysteine and ozone therapy on oxidative stress and inflammation in acetaminophen-induced nephrotoxicity model. Ren. Fail. 2013; 35 (5): 640-647.

40. Fruchter LL, Alexopoulou I, Lau KK. Acute interstitial nephritis with acetaminophen and alcohol intoxication. Ital. J. Pediatr. 2011; 37: 17.

41. Karthivashan G, Kura AU, Arulselvan P, Md Isa N, Fakurazi S. The modulatory effect of Moringa oleifera leaf extract on endogenous antioxidant systems and inflammatory markers in an acetaminophen-induced nephrotoxic mice model. PeerJ. 2016; 4: e2127.

42. Munoz-Felix JM, Oujo B, Lopez-Novoa, JM. The role of endoglin in kidney fibrosis. Expert Rev. Mol. Med. 2014; 16: e18.

43. Madjene LC, Pons M, Danelli L, Claver J, Ali L, Madera-Salcedo IK et al. Mast cells in renal inflammation and fibrosis: lessons learnt from animal studies. Mol. Immunol. 2015; 63 (1): 86-93.

44. Tonomura $\mathrm{Y}$, Tsuchiya $\mathrm{N}$, Torii $\mathrm{M}$, Uehara $\mathrm{T}$. Evaluation of the usefulness of urinary biomarkers for nephrotoxicity in rats. Toxicology. 2010; 273 (1-3): 53-59.

45. Hua H, Ge X, Wu M, Zhu C, Chen L, Yang G, Zhang Y, Huang S, Zhang A, Jia Z: Rotenone Protects Against Acetaminophen-Induced Kidney Injury by Attenuating Oxidative Stress and Inflammation. Kidney Blood Press Res 2018;43:1297-1309. doi: $10.1159 / 000492589$

46. Shimizu MH, Coimbra TM, de Araujo M, Menezes LF, Seguro AC. N-acetylcysteine attenuates the progression of chronic renal failure. Kidney Int. 2005; 68 (5): 2208-2217.

47. Ghosh J, Das J, Manna P, Sil PC. Acetaminophen induced renal injury via oxidative stress and TNFalpha production: therapeutic potential of arjunolic acid. Toxicology. 2010; 268 (1-2): 8-18.

48. Chen N, Aleksa K, Woodland C, Rieder M, Koren, $\mathrm{G}$. The effect of N-acetylcysteine on ifosfamideinduced nephrotoxicity: in vitro studies in renal tubular cells. Transl. Res. 2007; 150 (1): 51-57. 
49. Hanly L, Rieder MJ, Huang SH, Vasylyeva TL, Shah RK, Regueira O. et al. N-acetylcysteine rescue protocol for nephrotoxicity in children caused by ifosfamide. J. Popul. Ther. Clin. Pharmacol. 2013; 20 (2): e132-145.

50. Shalby AB, Assaf N, Ahmed HH. Possible mechanisms for $\mathrm{N}$-acetyl cysteine and taurine in ameliorating acute renal failure induced by cisplatin in rats. Toxicol. Mech. Methods. 2011; 21 (7): 538-546.

51. Wang L, Wang Z, Liu J. Protective effect of $\mathrm{N}$-acetylcysteine on experimental chronic lead nephrotoxicity in immature female rats. Hum. Exp. Toxicol. 2010; 29 (7): 581-591.

52. Schrier RW. Diseases of the Kidney and Urinary Tract 8th Ed. Philadelphia, USA: Wolters Kluwer Health/Lippincott Williams \& Wilkins. 2007; PP: 930-1200.

53. Sun Z, Fu Q, Cao L, Jin W, Cheng L, Li Z. Intravenous $\mathrm{N}$-acetylcysteine for prevention of contrast-induced nephropathy: a meta-analysis of randomized, controlled trials. PLoS One. 2013; 8 (1): e55124.

54. Betten DP, Burner EE, Thomas SC, Tomaszewski C, Clark RF. A retrospective evaluation of shortened-duration oral $\mathrm{N}$-acetylcysteine for the treatment of acetaminophen poisoning. J. Med. Toxicol. 2009; 5 (4): 183-190.
55. Cai Z, Lou Q, Wang F, Li E, Sun J, Fang H, Xi J \& $\mathrm{Ju} \mathrm{L}$. N-acetylcysteine protects against liver injure induced by carbon tetrachloride via activation of the Nrf2/HO-1 pathway. Int. J. Clin. Exp. Pathol. 2015; 8 (7): 8655-8662

56. Moldeus P, Cotgreave IA, Berggren M. Lung protection by a thiol-containing antioxidant: N-acetylcysteine. Respiration. 1986; 50 Suppl 1: 31-42.

57. Santus P, Corsico A, Solidoro P, Braido F, Di Marco F, Scichilone N. Oxidative stress and respiratory system: pharmacological and clinical reappraisal of $\mathrm{N}$-acetylcysteine. COPD. 2014; 11 (6): 705-717.

58. Wernerman J, Luo, JL, Hammarqvist F. Glutathione status in critically-ill patients: possibility of modulation by antioxidants. Proc. Nutr. Soc. 1999; 58 (3): 677-680.

59. Gupta RC. Veterinary Toxicology: Basic and Clinical Principles 2nd Ed. London: Elsevier Science. 2012; PP: 246-263.

60. Ebrahimi M, Mousavi S R, Toussi AG, Reihani $\mathrm{H}$, Bagherian $\mathrm{F}$. Comparing the therapeutic effectiveness of $\mathrm{N}$-acetylcysteine with the combination of $\mathrm{N}$-acetyl cysteine and cimetidine in acute acetaminophen toxicity: A double-blinded clinical trial. Electron. Physician. 2015; 7 (6): 1310-1317. 
الملخص العربى

\section{ن-اسيتيل سيستايين يخفف التغيرات التركيبية المحدثة بالاستخدام

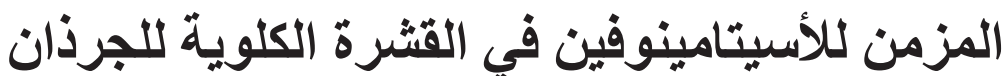 \\ عونى حسن إبراهيم يس، سمر عادل محمد عسكر، نسرين مصطفى محمد عمر، أمانى عبد القتـاح محمد عبد القتــاح}

قسم الأنسجة الطبية وبيولوجيا الخلية كلية الطب- جامعة المنصورة

المقدمة: يُعتبر الأسيتامينوفين احد العقاقير المسكنة و الخافضة للحر ارة الفعالة والتى تُشتخدم على نطاق واسع، ويُعد نـ اسيتيل سيستايين أحد مضادات الأكسدة الاصطناعية والذي يعمل ككاسح للجذور الحرة. الهـف من البحث: تم تصميم هذا العمل لاظهار تأثثر ن- اسيتيل سيستايين علي التعير ات النسيجية المحدثة بالاستخدام المزمن للأسيتامينوفين في القشرة الكلوية.

أدوات وطرق البحث: تم استخدام أربعين من ذكور الجرذان البيضاء موزعة على أربع مجموعات. المجمو عة الضابطة تم اعطائها الماء المقطر, مجموعة ال NAC- نم اعطائها ن- اسيتيل سيستايين 150 مج /كجم مرة واحدة يوميا لمدة 4 4اسابيع , مجموعة ال Aceta- تم اعطائها الأسيتامينوفين 300 مج /كجم/يوم عن طريق الفم مرة واحدة يوميا لمدة 4 اسابيع , مجمو عة ال Aceta+NAC ثم اعطائها الأسيتامينوفين 300 مج /كجم/يوم ثم ن- اسيتيل سيستايين 150 مج / كجم بعد التناول الفمي للأسيتامينوفين بساعتين مرة واحدة يو ميا لمدة 4 اسابيع, تم أخذ عينات صغيرة من القترة الكلوية و تجهيز ها للار اسة بالميكروسكوب الضوئي و الإلكتروني , كما تم تحديد مستويات نيتروجين اليوريا و الكرياتينين في

$$
\text { الدم , و أيضا إجر اء در اسات قياسية و إحصائية. }
$$

النتائج: نتج عن الاستخدام المزمن للأسيتامينوفين حدوث تشويه و انكماش في بعض الشعير ات الدموية الكُبيبية و تدمير جزئى لكبسو لات بومان, كما أظهرت الأنابيب الملتوية القريبة وجود اتساعات و تغير ات تحللية و فقدان الحافة المخططة العلوية بالإضافة إلي حدوث التسلل الخلوى الإلتهابى و ترسيب للألياف الكولاجينية فى الأنسجة الخلالبة للكلية, وقد أظهرت الدر اسة بالميكروسكوب الالكتروني زيادة غير منتظمة فى سُمك الغشاء القاعدى للثُعيرات الدموية الكُبيبية وفقدان لمظهره ثناثي الطبقات , كما أظهرت الخلايا المبطنة للأنابيب الملتوية القريبة وجود أنوية كثيفة الصبغة غير منتظمة وفجوات سيتوبلازمية و فقدان للخُميْلات الدقيقة العلوية و قد كانت هذه التغير ات مصحوبة بزيادات ملحوظة في مستو سات نيتروجين اليوريا و الكرياتينين في الام, و أدى تناول NAC إلى تحسن جزئي في التركيب النسيجي للكلية

$$
\text { و انخفاض ملحوظ في مستويات نبتروجين اليوريا و الكرياتينين في الدم. }
$$

الإستتتاج: يمكن ل ن- اسيتيل سيستايين أن يخفف من التغير ات النسيجية ، و الكيميائية الحيوية الناجمة عن الاستخدام المزمن للأسيتامينوفين في القشرة الكلوية للجرذان. 